\title{
Determinants of Food Security Status of Maize-Based Farming Households in Southern Guinea Savannah Area of Oyo State, Nigeria.
}

\author{
Oluwayemisi Abidemi Onasanya, Oluwakemi Adeola Obayelu*
}

Department of Agricultural Economics, Faculty of Agriculture and Forestry, University of Ibadan, Ibadan, Nigeria A R T I C L E I N F O

Article history:

Received 09 September 2015

Accepted 03 May 2016

Available online, ISSN: 2148-127X

Keywords:

Per Capita Daily Calorie Requirement

Headcount ratio

Shortfall index

Maize

Rural

${ }^{*}$ Corresponding Author:

E-mail: jkemmyade@yahoo.co.uk

A B S T R A C T

Nigeria is one of the countries in sub-Saharan Africa with insufficient food and high food import bill, which have debilitating effects on the productive capacity of the citizens. Maize is the most important cereal after rice and its production contributes immensely to food availability on the tables of many Nigerians. This study examined the contribution of maize production to household food security status of rural maize-farming households in the southern guinea savannah of Oyo state, Nigeria. A multistage sampling procedure was used to select 200 farm households and the data were analysed using descriptive statistics, recommended daily calorie requirement (RDCR) approach, Logit model. Results showed that about three-quarters of the households were food secure and were able to meet the recommended calorie intake of $2260 \mathrm{Kcal}$ per capita per day. The shortfall index $(\mathrm{P})$ which measures the extent of deviation from the food security line, indicated that the food secure households exceeded the RDCR by $65 \%$, while the food insecure households fell short of the RDCR by $31 \%$. The logit model showed that maize output, gender, primary occupation of the farmer, farm size and farming experience had a positive influence on food security status while age had a negative influence on the food security status of maize-based farming households in the Southern Guinea Savannah of Oyo State, Nigeria. This suggests need for specific support to improve maize production.

\section{Introduction}

The idea of food security emerged between 1972 and 1974 during a global food crisis with the initial focus on national and global food availability. The focus later shifted to individual and household units of analyses in the 1980s (Maxwell and Frankenberger, 1992; Clay, 2002; Mequanent, 2014). Food security occurs when all people, at all times, have physical, social and economic access to sufficient, safe and nutritious food that meets their dietary needs and food preferences for an active and healthy life (FAO, 2010). Despite the persistent decline in global hunger, about 795 million people are chronically hungry and cannot lead a healthy active life (FAO/IFAD/WFP, 2014). However, progress has been slow overall in sub-Saharan Africa, despite many success stories at country and sub-regional levels. Although, there is a slow decline in the prevalence of undernourishment in the region, the absolute number of undernourished is increasing in the region. Thus, encouraging global downward trend in the reduction of hunger is not experienced in the sub-Saharan Africa, which still has the highest prevalence of $223.2 \%$ under-nourishment in the world (Kumba, 2015). This situation led to the declaration of 2014 as the Year of Agriculture and Food Security by the African Union, in line with its commitment to use political will to end hunger in the continent by the year 2025 .
In Nigeria, the percentage of food insecure households rose from $18 \%$ in 1986 to $40 \%$ in 2005 (Sanusi et al., 2006). Recently, proportion of hungry people in the country was estimated at over 53 million, which is about $30 \%$ of the country's total population of roughly 150 million. The Nigerian Comprehensive Food Security and Vulnerability Analysis (CFSVA) revealed that about 29 percent of households in the poorest wealth quintiles have unacceptable diets $(9$ percent poor and 20 percent borderline) compared with 15 percent in the wealthiest ( 2 percent poor and 13 percent borderline). The poorest livelihoods are found in agriculture and seventy-seven percent of subsistence farmers are found in the two poorest wealth quintiles (Kuku-Shittu et al., 2013). The Global Food Security Index (GFSI), of the Economist Intelligence Unit ranked Nigeria as the 80th among 105 countries in 2012 and $91^{\text {st }}$ in 2015 with food affordability, availability and quality. These are matters of grave concern largely because Nigeria was once self-sufficient in food production and was indeed a net exporter of food to other regions of the continent in the 1950s and 1960s.

Cereals have been known to be major foods in achieving food security of any nation. Maize is one of the world's most important cereals along with wheat and rice. Maize is currently produced on nearly 100 million hectares in 125 developing countries and is among the 
three most widely grown crops in 75 of those countries (FAOSTAT, 2010). Although much of the world's maize production (approximately 78\%) is utilized for animal feed, human consumption in many developing and developed countries is steadily increasing. The growing demand for food consumption in developing countries alone is predicted to increase by around $1.3 \%$ per annum until 2020 (Ortiz et al. 2010). By 2050, the demand for maize in the developing world will double, and by 2025 , maize is likely to become the crop with the greatest production globally (Rosegrant et al. 2008). This points to the significant role of maize production to sustainable development of rural economy, food security and poverty reduction especially in rural areas of Nigeria. Maize has now risen to a commercial crop on which many agrobased industries depend on as raw materials (Iken and Amusa, 2004).

Maize is a major important cereal crop being cultivated in the rainforest and the savannah agroecological zones of Nigeria and it has been in the diet of Nigerians for centuries. It is one of the important grains in Nigeria, not only on the basis of the number of farmers that are engaged in its cultivation, but also on its economic value (Ogunlade et al., 2010; Olaniyi and Adewale, 2012). Introduced in Nigeria in the 16th century, maize is the fourth most consumed cereal during the past two decades, below sorghum, millet and rice (FAOSTAT 2012). Being among the primary food staples, maize consumption is widespread across the country and among households of different wealth. Following a peak in 1994 (35 Kg/year), per capita consumption of maize in Nigeria underwent an overall decrease throughout the 1990s, reaching a negative peak in $2000(17 \mathrm{Kg} /$ year $)$ with a positive growth rate between 2001 and 2007 (aside from 2006, when the per capita consumption declined by 0.4 percent) (FAOSTAT 2012).

Despite the economic importance of maize to the teeming populace in Nigeria, it has not been produced to meet food and industrial needs of the country (Onuk et al., 2010). The demand for maize sometimes outstrips supply as a result of the various domestic uses (Akande, 1994) and this has negative consequences for household food security. According to IITA, maize demand in the country is estimated to increase 3.2 percent per year due a perspective growth of urbanization and population. IITA estimates that approximately 60 percent of maize produced in the country is used for industrial end uses for both for human (flour, beer, malt drinks, cornflakes, starch, dextrose, syrup) and animal consumption, mainly poultry (UNIDO 2010). This study therefore investigated the food security status of maized-based farming households in the derived guinea savannah region of Oyo state, Nigeria.

\section{Material and Method}

Primary data for this study were collected in 2014 during the post-planting period through the use of a wellstructured questionnaire administered through direct interviews to rural farming households in the study area.
A multistage sampling procedure was employed to obtain information from 200 farming households in the southern guinea savannah. The first stage was the random selection of two major grain zones (Oyo and Saki) from the four zones of the Agricultural Development Programme (ADP) zones in Oyo state. ADP zonal classifications were used owing to the fact that the study focused on rural households, whose primary livelihood is farming. The second stage was the random selection of the two Blocks of each the ADP zones. Given the higher population of Saki zone relative to that of Oyo zone, four cells and three cells were randomly selected from each of the Blocks in Saki and Oyo zones respectively, at the third stage, leading to a total of 14 cells in all. At the final stage, respondents were randomly selected from each of the cells proportionate to the population size of the cells. In all, 80 and 120 households were sampled in Oyo and Saki zones respectively.

Information obtained from the respondents include the household socio-economic and demographic characteristics; household food consumption; asset ownership; and varieties of maize grown and consumed in the study area. The data were analysed using descriptive statistics, food security index (the Recommended Daily Calorie Required) and the Logit regression. The first step of the analyses was to construct a Food Security Index $\left(Z_{i}\right)$ and then to determine the food security status of each household based on the food security line using the Recommended Daily Calorie Required (RDCR) approach following Demi and Kuwornu (2013). Households whose Daily Calorie Intake equalled or higher than RDCR (2260 Kcal) was considered food secure households and those whose Daily Calorie Intake fell below the RDCR were considered food insecure households. The Food Security Index is given as:

$$
Z_{i}=\frac{Y_{i}}{R}
$$

Where;

$\mathrm{Z}_{i}=$ Represents Food Security Index of $\mathrm{i}^{\text {th }}$ household, $\mathrm{Y}_{i}=$ Actual Daily Calorie Intake of $\mathrm{i}^{\text {th }}$ households,

$\mathrm{R}=$ Recommended Daily Calorie Requirement of $\mathrm{i}^{\text {th }}$ household.

To obtain Per Capita Daily Calorie Intake; daily calorie intake of each household were divided by its' household size. Households' per Capita Daily Calorie Requirement was obtained by dividing the households' Daily Calorie Requirement by household size. Based on the food security index that was estimated, the study further estimated other indices such as food insecurity gap (FIG), headcount ratio (HCR) and Surplus Index (SI). The food insecurity gap (FIG) measures the extent to which food insecure households on average fall below the food security line and the food surplus index (SI) measures the extent by which food secure households exceeded the food security line. The Headcount ratio (HCR) measures ratio of food secure households to the total number of households. Food insecurity/shortfall gap is given as: 


$$
\frac{1}{M} \sum_{i=1}^{n} G_{i}
$$

Where;

$\mathrm{M}=$ Represents the number of food insecure households

$\mathrm{G}_{i}=$ Calorie intake deficiency for the $\mathrm{i}^{\text {th }}$ households.

$\mathrm{G}_{i}$ was further expanded in a form:

$$
G_{i}=\left(\frac{Y_{i}-R}{R}\right)
$$

Where; $Y$ and $R$ as defined previously (above). The headcount ratio (HCR) is given as:

$$
\frac{M}{N} * 100 \%
$$

Where, $N$ represents the number of households in the sample. The Surplus index (SI) is given by:

$$
\frac{1}{M} \sum_{i=1}^{n}\left(\frac{R-Y_{i}}{R}\right)
$$

\section{Regression Model}

A binary logistic regression model was used to determine the effects of some socio-economic and demographic characteristics of the households on their food security status. The binary logistic specification is suited to models where the endogenous variable is dichotomous, which in this case are the households who are food secure and those who are food insecure. Food security status was measured using a bid value of one or zero, where one represents food secure and zero represents food insecure. The logistic regression then provides a model of observing the probability of a household becoming food secure or food insecure. The selection of variables likely to influence household food security relies on previous studies by Oni and Fashogbon (2012), Babatunde et al. (2007), Kuwornu et al., (2013), Ibok et al., (2014) and Omotesho et al., (2010). The regression model will be estimated as follows:

$P(Y=1)=\frac{1}{1}+\exp [-\propto(\alpha+\beta 1 \times 1+\beta 2 \times 2 \ldots \ldots \ldots k x k)]$

The whole function is called the logistic distribution function and it is estimated by maximum likelihood (MLE) techniques. An advantage of this function is that it guarantees that the probability ranges from 0 to 1 as the regression equation predicts values from negative infinity to positive infinity (Cameron and Trivedi, 2005). It is also called log-odds as we can write logistic function as:

$$
\begin{aligned}
& \operatorname{Logit}[\mathrm{p}(\mathrm{Y}=1)]=\propto+\beta 1 \mathrm{x} 1+\beta 2 \mathrm{x} 2+\beta 3 \mathrm{x} 3 \ldots \ldots \ldots \mathrm{kxk} \\
& \operatorname{Logit}[\mathrm{p}(\mathrm{Y}=1)]=\log \mathrm{e}\left(\frac{\mathrm{p}=1}{1}-\mathrm{p}(\mathrm{y}=1)\right)
\end{aligned}
$$

This fits the model;

$\operatorname{Ln}\left(\frac{\mathrm{p}}{1-\mathrm{p}}\right)=\alpha+\sum$ bixi

Where;

$\mathrm{Y}=$ Food security status ( 1 if household is food secure; 0 , if otherwise),

$\mathrm{p}=$ The probability of household having food insecurity,

$\propto$ =Shows the intercept term,

$\beta_{\mathrm{i}}=$ Estimated regression coefficients,

$\mathrm{x}_{\mathrm{i}}=$ The background socio-demographic characteristics consisting of age of household head, gender of household head, membership of cooperatives, livelihood activities of household head, household size, education level of household head, farm size, quantity of own production, access to extension services, annual non-farm income including remittances to household, access to credit, dependency ratio, annual gross farm income.

\section{Results and Discussion}

Table 1 presents the summary statistics and food security indices among sampled households. A typical rural household head is in his middle-age (51.5 years) and had six household members. An average food insecure household had larger households than their food secure counterparts. The average income of food secure households was more than twice the average income of food insecure households. However, food insecure households had slightly higher hectare of farmland than food secure households and overall estimate. Based on the RDCR of $2260 \mathrm{Kcal}$, results showed that about threequarters of the households were food secure and were able to meet the recommended calorie intake of $2260 \mathrm{Kcal}$ per capita per day. The shortfall/surplus index (P) which measures the extent of deviation from the food security line, shows that the food secure households exceeded the RDCR by $65 \%$, while the food insecure households fell short of the RDCR by $31 \%$.

Food Security Profile of Rural Maize Farming Households

Food security profile of rural maize-based farming households is presented in Table 2. A typical maizefarming household head was a male, within the age range of 30 to 59 years, married and a Christian with five to nine household members. About $62.5 \%$ and $78.4 \%$ of the female-headed and the male-headed households were food secure respectively while $82.3 \%$ and $70.8 \%$ of those whose heads were within 30 to 49 years old and 50 to 59 years respectively were food secure. About half of the sampled households had five to nine members with about three-quarters of them being food secure. 
Table 1 Summary statistics of food security index.

\begin{tabular}{l|ccc}
\hline \multirow{2}{*}{ Variables Food Security Indices } & \multicolumn{3}{c}{ Mean } \\
\cline { 2 - 4 } & Food Secure & Food Insecure & All \\
\hline RDCR = 2260 Kilocalorie & & & 100 \\
Percentage of households & 76.5 & 23.5 & 200 \\
Number of households & 153 & 47 & 51.49 \\
Age of household heads & 50.10 & 52.87 & 6.77 \\
Household Size & 6.67 & 8.60 & 156075.00 \\
Household annual farm income (N) & 281808.51 & 117450.98 & 5.28 \\
Farm size (Ha) & 5.16 & 5.64 & 1.493 \\
Food Security index (Z) & 1.724 & 0.740 & 0.815 \\
Mean & 0.792 & 0.208 & 3374.14 \\
Standard deviation & 3721.4 & 1565.47 & - \\
Per capita daily calorie availability & 0.65 & 0.31 & - \\
Shortfall/Surplus index & 0.765 & 0.235 & \\
Head count ratio & & \\
\hline
\end{tabular}

Table 2 Food security profile of rural maize-based farming households

\begin{tabular}{|c|c|c|c|}
\hline Demographic characteristics & Food secure $(\mathrm{N}=153)$ & Food insecure $(\mathrm{N}=47)$ & All $(\mathrm{N}=200)$ \\
\hline \multicolumn{4}{|l|}{ Gender } \\
\hline Male & 90.20 & 80.85 & 88 \\
\hline Female & 9.80 & 19.15 & 12 \\
\hline Total & 100.00 & 100 & 100 \\
\hline \multicolumn{4}{|l|}{ Age of $\mathrm{HH}$} \\
\hline$<29$ & 0.65 & 2.13 & 1 \\
\hline $30-49$ & 51.63 & 36.17 & 48 \\
\hline $50-69$ & 44.44 & 57.45 & 48 \\
\hline 70 and above & 3.26 & 3.27 & 3 \\
\hline Total & 100.00 & 100.00 & 100 \\
\hline \multicolumn{4}{|l|}{ Religion } \\
\hline Christian & 66.67 & 65.96 & 66.5 \\
\hline Islam & 33.33 & 31.91 & 33 \\
\hline Others & 0 & 2.13 & 0.5 \\
\hline Total & 100.00 & 100.00 & 100 \\
\hline \multicolumn{4}{|l|}{ Household Size } \\
\hline$<5$ & 3.27 & 2.13 & 3 \\
\hline $5-9$ & 50.33 & 51.06 & 50.5 \\
\hline $10-14$ & 24.84 & 34.04 & 27 \\
\hline$>14$ & 21.57 & 12.77 & 19.5 \\
\hline Total & 100.00 & 100.00 & 100 \\
\hline \multicolumn{4}{|l|}{ Marital Status } \\
\hline Single & 1.96 & 10.64 & 4.00 \\
\hline Married & 92.81 & 78.72 & 89.5 \\
\hline Divorced & 1.96 & 2.13 & 2 \\
\hline Widowed & 3.27 & 8.51 & 4.5 \\
\hline Total & 100 & 100 & 100 \\
\hline
\end{tabular}

A typical maize-based farmer had primary education and 19 years of farming experience. He also had extension contact, five to nine hectares of farmland and was a member of cooperative society but had no access to credit. Three-quarters of the food secure household heads had access to formal education and a minimum of ten years of farming experience, while about $68.09 \%$ and about two-fifth of the food insecure households had access to formal education and a minimum of ten years of farming experience respectively. About two-thirds of food secure households had also had access to over five hectares of farmland. Further, a higher percentage of households with cooperative membership and extension contact were food secure.
Factors Influencing Food Security Status of MaizeBased Rural Households

The determinants of food security are identified in Table 5. The likelihood ratio and the wald tests were significant $(\mathrm{P}<0.05)$ indicating that the coefficients are not simultaneously equal to zero. The null hypothesis was rejected and the alternative hypothesis was accepted that all the variables jointly explained the food security status of the maize-based farming households. The HosmerLemeshow test $(\mathrm{P}=0.385)$ indicated that the numbers of food secure households were not significantly different from those predicted by the model and that the overall fitness of the model was good. Six variables significantly explained the variations in food security status among the 
rural maize-based farming households. These variables were maize output, gender, farm size, age, primary occupation and farming experience. All the variables except age and farm size had positive relationships with food security status of the households.

Maize output had a positive relationship with food security status of the maize farming households. However, its marginal effect on the food security status of the maize households is very minimal suggesting increasing the maize output will improve the food security status of the rural farming households. This buttresses the findings of Babatunde et al., (2007), Quaino (2010), Pappoe (2010) and Ojogho (2010) and that increasing farm output level increases food security status of arable farmers. Growth in food production can be accelerated extensively through expansion of land areas under cultivation and households with large farm size can produce more and also diversify (Van Der Veen, 2010 in Tefera and Tefera, 2014). Farm size also had a positive influence on the food security status of maize-based farming households. The odds ratio and the marginal effect in favor of food security increased by the factor 0.834 and 0.028 units respectively when the area under cultivation was increased by one hectare. This is in consonance with the findings of Chepkirui et al., (2014) and Tefera and Tefera (2014) that farm size allocated to food crops had positive effect on food security among small-scale farmers in Kenya and Ethiopia respectively.
The age of the household head, has negative coefficient suggesting that households with younger heads were more likelihood to be innovative, engaged in multidimensional livelihood strategies and consequently more food secure than their elderly counterparts (Tekle and Berhanu, 2015). A year increase in the age of a household head reduced the odds ratio and the marginal effect of household's food security by a factor of 0.961 and 0.01 unit respectively. This is in line with the findings of Babatunde et al., (2007) that households whose heads were between the ages 18 - 65years old were more likely to be food secure than their other counterparts. The odds ratio increased by 2.59 if the household head were a man. The primary occupation of household heads had a positive coefficient indicating that households whose heads were primarily engaged in farming were more food secure than those whose heads were primarily non-farmers. In other words, farming households were more likely to be food secure than non-farming households. The coefficient of farming experience was positively related to food security implying that over the years, farmers gained experience in their enterprise which could improve their level of expertise and output. Also, the odds ratio and the marginal effect of food security increased by 1.107 and 0.016 units respectively, with a year increase in the years of farming experience.

Table 3 Food security status and capital assets

\begin{tabular}{|c|c|c|c|}
\hline Economic characteristics & Food secure $(\mathrm{N}=153)$ & Food insecure $(\mathrm{N}=47)$ & Total $(\mathrm{N}=200)$ \\
\hline \multicolumn{4}{|l|}{ Education } \\
\hline None & 23.53 & 27.66 & 24.5 \\
\hline Primary School & 46.41 & 38.30 & 44.5 \\
\hline Secondary School & 29.41 & 29.79 & 29.5 \\
\hline Tertiary School & 0 & 0 & 0 \\
\hline Others(Islamic School) & 0.65 & 4.26 & 1.5 \\
\hline Total & 100.00 & 100.00 & 100 \\
\hline \multicolumn{4}{|l|}{ Years of Farming Experience } \\
\hline $1-9$ & 22.88 & 38.30 & 26.5 \\
\hline $10-19$ & 65.36 & 53.19 & 62.5 \\
\hline 20 and above & 11.76 & 8.51 & 11 \\
\hline Total & 100 & 100 & 100.0 \\
\hline \multicolumn{4}{|l|}{ Farm Size (ha) } \\
\hline Less than 5 & 32.68 & 36.17 & 27.5 \\
\hline $5-9$ & 48.37 & 51.06 & 59.5 \\
\hline $10-14$ & 18.95 & 11.77 & 13 \\
\hline Total & 100 & 100 & 100 \\
\hline \multicolumn{4}{|l|}{ Access to Credit } \\
\hline Yes & 26.14 & 31.91 & 27.5 \\
\hline No & 73.86 & 68.09 & 72.5 \\
\hline Total & 100 & 100 & 100 \\
\hline \multicolumn{4}{|l|}{ Membership of Cooperative } \\
\hline Yes & 64.05 & 53.19 & 61.5 \\
\hline No & 35.95 & 46.81 & 38.5 \\
\hline Total & 100 & 100 & 100 \\
\hline \multicolumn{4}{|l|}{ Extension Contact } \\
\hline Yes & 30.72 & 40.43 & 67 \\
\hline No & 69.28 & 59.57 & 633 \\
\hline Total & 100 & 100 & 100 \\
\hline
\end{tabular}


Table 4 Determinants of food security status of rural maize-based households.

\begin{tabular}{l|rrr}
\hline \multicolumn{1}{c|}{ Variables } & \multicolumn{1}{c}{ Coefficient } & \multicolumn{1}{c}{ Odds Ratio } & Marginal Effects \\
\hline Age of household head & $-0.040^{* *}(0.020)$ & $0.961(0.019)$ & $-0.0061^{* *(0.003)}$ \\
Sex of household head & $0.951^{* *}(0.531)$ & $2.589(1.374)$ & $0.178(0.115)$ \\
Household size & $-0.044(0.000)$ & $0.957(0.036)$ & $-0.007(0.006)$ \\
Educational status of household head & $-4.33 \mathrm{e}-06(9.49 \mathrm{e}-06)$ & $0.999(9.49 \mathrm{e}-06)$ & $-6.65 \mathrm{e}-07(0.000)$ \\
Maize output & $0.000^{*}(0.000)$ & $1.000(0.000)$ & $0.000^{*}(0.000)$ \\
Dependency ratio & $0.101(1.037)$ & $1.107(1.148)$ & $0.016(0.159)$ \\
Farming experience (years) & $0.102 * *(0.045)$ & $1.107(0.050)$ & $0.016^{* *}(0.007)$ \\
Access to consumption credit & $-0.521(0.413)$ & $0.594(0.245)$ & $-0.086(0.073)$ \\
Primary occupation & $0.995^{* *}(0.432)$ & $2.705(1.168)$ & $0.179 * *(0.087)$ \\
Membership of cooperative society & $-0.434(0.376)$ & $0.648(0.243)$ & $-0.069(0.061)$ \\
Farm size & $0.181 * *(0.091)$ & $0.834(0.076)$ & $-0.028^{* *}(0.014)$ \\
Extension contact & $-0.551(0.393)$ & $0.576(0.227)$ & $-0.085(0.059)$ \\
cons & $1.573(1.484)$ & $4.822(7.154)$ & - \\
\hline
\end{tabular}

LR chi-square $(12)=28.32 ;$ Prob $>$ chi $^{2}=0.0050$; Pseudo $\mathrm{R}^{2}=0.13$; Wald Test Chi-square $(12)=21.78 ;$ Prob $>$ chi ${ }^{2}=0.0401 ;$ Logistic model for food security, goodness-of-fit test (Table collapsed on quantiles of estimated probabilities); Number of observation = 200; Number of groups = 10; Hosmer-Lemeshow $\mathrm{chi}^{2}(8)=8.51$ Prob $>\mathrm{chi}^{2}=0.3854$

\section{Conclusion}

Results showed that the majority of the food secure farming household heads were male, married, had formal education and access to credit. Thus, Access to credit and formal education are policy tools to achieve household food security. Maize output, farm size, being a farming male-headed household and having long years of farming experience had positive influence while age had a negative influence on the food security status of the rural households. This suggests the need for specific support to improve maize production. Male-headed households were more food secure than their female counterparts. Thus, age and gender-specific programmes should be an integral part of food security and rural development policies in Nigeria as this will help to ameliorate the food security status of the vulnerable, maize-based, aging and femaleheaded households.

The Federal Government can aid increased access to farm land through the review of the Nigerian land-use decree of 1978 while the State Government could facilitate options like expansion of farm settlement scheme. These suggestions would enhance increased access to farmlands and increase maize output, which would consequently translate to improved food security status among the rural households. Further, being primarily a farming household also increased the likelihood of being food secure. Thus, in order to increase maize production in the guinea savannah (with a favourable climatic condition for maize production) and improve the food security status of maize farmers, government should intensify efforts towards creating a favourable agricultural policy climate that will promote sustainable agricultural growth, especially maize output, for the rural smallholder farmers. All these could be promising ways of achieving the second of the Sustainable Development Goals of ending hunger.

\section{References}

Akande SO. 1994. Comparative Cost and Return in Maize Production in Nigeria. Nigeria Institute for Social and Economic Research (NISER) Individual Research Project Report, Ibadan, Nigeria.

Babatunde RO, Owotoki GM, Heidhues F and Bucheenrieder G. 2007.Vulnerability and Food Insecurity Differentials among Male and Female-Headed Farming Households in Nigeria. Pakistan Journal of Social Sciences, 4(3): 414-418.

Chepkirui BR, Mwangi, JG and Kibett JK. 2014. Effects of Farm Size Under Food Crops on Food Security among Small-Scale Farmers in Kakamega Central Sub-County, Kenya. International Journal of Advanced Research 2(10): 592-599.

Demi SM and Kuwornu JKM.. 2013. Assessing the Degree of Food Insecurity among Farming Households: Evidence from the Central Region of Ghana. Research on Humanities and Social Sciences, 3(3):51-61.

Clay E. 2002. Food security: Concepts and Measurement. Paper for FAO Expert Consultation on Trade and Food Security: Conceptualizing the Linkages, Rome, 11-12 July 2002, pp: 1-7.

FAO. 2010. The State of Food Insecurity in the World 2010: Addressing Food Insecurity in Protracted Crises. Food and Agriculture Organization of the United Nations, Rome, Italy, ISBN-13: 9789251066102, Pages: 57.FAOSTAT 2012. Food and Agriculture Organisation Statistics. FAO, Rome.

FAO/ IFAD/WFP. 2015. The State of Food Insecurity in the World 2015. Meeting the 2015 International Hunger Targets: Taking Stock Of Uneven Progress FAO, Rome.

Global Food Security Index (GFSI). 2012. and 2015. The State of Food Insecurity in the world: An Annual Measure of the State of Global Food Security.

Ibok OW, Bassey NE, Atairet EA, Obot OJ. 2014. Food Security Determinants among Urban Food Crop Farming Households in Cross River state, Nigeria. Asian Journal of Agricultural Extension, Economics and Sociology 3(1):76-90.

Iken JE, and Amusa NA. 2004. Maize Research and Production in Nigeria. African Journal of Biotechnology 3(6): 302-307.

Kuku-Shittu O, Mathiassen A, Wadwa A, Myles L and Ajibola A. 2013. Comprehensive Food Security and Vulnerability Analysis: Nigeria. Nigeria Strategy Support Program. IFPRI Discussion Paper 01275.

Kumba JK. 2015. The Role of Household Characteristics in Determining Food Security in Kisii Central Sub-County, Kenya. Research on Humanities and Social Sciences, 5(7):186-193. 
Kuwornu JKM., Suleyman DM and Amegahie DM. 2013. Analysis of Food Security Status of Farming Households in the Forest Belt of the Central Region of Ghana. Russian Journal of Agricultural and Socio-Economic Science, 1 (13). University of Ghana, Legon-Accra, Ghana

Maxwell S and Frankenberger, T. 1992. Household food security: Concepts, indicators, measurements. A. Technical review. New York. NY: UNICEF and Rome: I FAD.

Mequanent, M., Birara E and Tesfalem K. 2014. Determinants of Household Food Security among Southwest Ethiopia Rural Households. Asian Journal of Agricultural Research, 8: 248258.

Ogunlade I, Olaoye G, Tologbonse D and Alaoye OEA. 2010. Onfarm Evaluation of Drought Tolerant Maize Varieties and Hybrids in the Southern Guinea Savanna Zones of Nigeria Proceedings of the 44th Annual Conference of the South African Society for Agricultural Extension, May 4-7, 2010, Langebaan, Western Cape, South Africa, pp: 1-5.

Ojogho O. 2010. Determinants of Food Insecurity among Arable Framers in Edo State, Nigeria. Agricultural Journal 5(3): 151156.

Olaniyi OA and Adewale JG. 2012. Information on Maize Production among Rural Youth: A Solution for Sustainable Food Security in Nigeria. Library Philosophy and Practice 2012 http://digitalcommons.unl.edu/cgi/viewcontent.cgi?article=1798 \&context=libphilprac

Omotesho OA, Adewumi MO and Fadimula KS. 2010. Food Security and Poverty of the Rural Households in Kwara State, Nigeria. Libyan Agriculture Resources Center Journal International, 1(1): 56-59.

Oni OA and Fashogbon AE. 2013. Food Poverty and Livelihoods Issues in Rural Nigeria. African Journal of Agricultural and Resource Economics, 8(2):108-135
Onuk EG, Ogara IM, Yahaya H and Nannim N. 2010. Economic Analysis of Maize Production in Mangu Local Government Area of Plateau State, Nigeria. PAT Journal, 6 (1): 1 - 11.

Ortiz-Monasterio I, Wassmann R, Govaerts B, Hosen Y, Katayanagi $\mathrm{N}$ and Verhulst N. 2010. Greenhouse Gas Mitigation in the Main Cereal Systems: Rice, Wheat And Maize. In Climate Change and Crop Production In M.P. Reynolds, Ed.), CABI Series in Climate Change Vol. 1, pp. 151-176, CABI, UK.

Pappoe P. 2011. Effect of Biofuel Production on Household Food Security in the Central Region of Ghana. Unpublished Thesis Submitted to the Department of Agricultural Economics and Agribusiness, University of Ghana.

Quaino ME. 2010. Food security implications of women farmers' participation in biofuel crop production in the Gomoa District. Unpublished MPhil Thesis submitted to the Department of Agricultural Economics and Agribusiness, University of Ghana, Legon.

Rosegrant MW, Msangi S, Ringler C, Sulser TB, Zhu T, and Cline SA. 2008. International Model for Policy Analysis of Agricultural Commodities and Trade (IMPACT): Model Description. International Food Policy Research Institute, Washington, D.C.

Sanusi RA, Badejo CA and Yusuf BO. 2006. Measuring Household Food Insecurity in Selected Local Government Areas of Lagos and Ibadan, Nigeria. Pak. J. Nutr., 5: 62-67.

Sen AK. 1981. Poverty and Famines: An Essay on Entitlement and Deprivation. Clarendon Press, Oxford.

Tefera T and Tefera F. 2014. Determinants of Households Food Security and Coping Strategies for Food Shortfall in Mareko District, Guraghe Zone Southern Ethiopia. Journal of Food Security 2.3 (2014): 92-99.

Tekle L, and Berhanu K. 2015. Determinants of Rural Farm Household Food Security in Boloso Sore District of Wolaita Zone in Ethiopia. Asian Journal of Agricultural Extension, Economics and Sociology, 5(2): 57-68. 